\title{
Achenbach's syndrome
}

\author{
João Filipe Gomes ำ , Jorge Mendes, David Donaire, Mafalda Ferreira
}

Department of Internal Medicine, Centro Hospitalar e Universitário de Coimbra EPE, Coimbra, Portugal

\section{Correspondence to Dr João Filipe Gomes; jomes84@gmail.com}

Accepted 4 August 2020
Check for updates

(C) BMJ Publishing Group Limited 2020. No commercial re-use. See rights and permissions. Published by BMJ.

To cite: Gomes JF, Mendes J, Donaire D, et al. BMJ Case Rep 2020;13:e238156. doi:10.1136/bcr-2020238156

\section{DESCRIPTION}

A previously healthy 45-year-old Portuguese woman presented to the emergency department in February 2020 with a sudden onset of pain in the fifth finger of her right hand. Subsequently, bruising appeared not only on that finger but also on the right thumb and thenar eminence (figure 1). This was accompanied by oedema and discolouration. She did not take any regular medication and denied previous similar episodes. There was no history of recent trauma or regular activities requiring physical exertion. A physical examination showed a subcutaneous haematoma and swelling with a normal capillary refill. There was no difference in blood pressure between the upper limbs and normal patency was shown by the Allen test. The discolouration was not related to cold exposure and other systemic symptoms were not observed. Laboratory tests showed no platelet deficiency or coagulopathy and all other results were normal, including C-reactive protein and autoantibody screening. The patient's condition resolved spontaneously within 5 days without any treatment. Based on the clinical presentation and course, we diagnosed Achenbach's syndrome.

Achenbach's syndrome, also known as 'paroxysmal finger haematoma' is a rare and benign clinical condition of unknown aetiology, which results in the sudden onset of pain and swelling along with bruising, mostly on the palmar aspects of fingers and hands. ${ }^{1-3}$ Although the most commonly affected anatomical site is the volar aspects of the fingers, ${ }^{4}$ there are occasional reports involving the palms, soles or toes. ${ }^{5}$ It is clearly predominant in women $(7: 1)^{5}$ in their fifth decade of life ${ }^{167}$ with a median age of 50 years. ${ }^{45}$ The subdermal bleeding usually stops spontaneously and although the patient's signs and symptoms often disappear within a few days without treatment, relapse can occur in a few cases. ${ }^{189}$ The main differential diagnosis
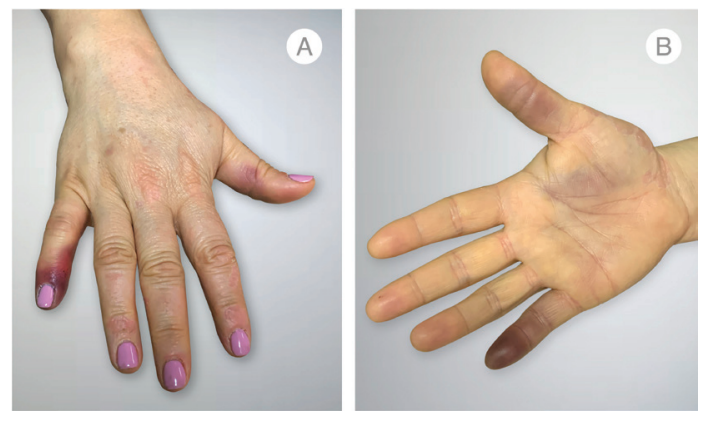

Figure 1 Typical features of Achenbach's syndrome in the fifth finger, thumb and thenar eminence of the right hand: (A) dorsal surface; (B) palmar surface.

\section{Learning points}

- Sudden onset of pain and discolouration of fingers and hands includes an extensive range of differential diagnoses, like acute upper extremity ischaemia, systemic vasculitis, Achenbach's syndrome and many others.

- Achenbach's syndrome is a rare and benign clinical condition whose diagnosis is essentially clinical.

- Physicians should be aware of this condition in order to address patient's concerns and to avoid unnecessary investigations and treatments.

of Achenbach's syndrome includes Raynaud's syndrome, ischaemic vasculopathy of the limbs, Buerger's disease, acrocyanosis, Gardner-Diamond syndrome, collagen diseases and Chilblains disease, among others. ${ }^{45}$ The diagnosis is mainly clinical and there is no specific prevention and treatment for this benign condition. ${ }^{19}$ Therefore, prompt diagnosis avoids unnecessary invasive procedures and may relieve patient anxiety. ${ }^{139}$

Contributors JFG conceived the original ideal and wrote the article with the support of JM, DD and MF.

Funding The authors have not declared a specific grant for this research from any funding agency in the public, commercial or not-for-profit sectors.

Competing interests None declared.

Patient consent for publication Obtained.

Provenance and peer review Not commissioned; externally peer reviewed.

\section{ORCID iDs}

João Filipe Gomes http://orcid.org/0000-0002-0680-9543

Mafalda Ferreira http://orcid.org/0000-0002-7504-3385

\section{REFERENCES}

1 Godoy A, Tabares AH. Achenbach syndrome (paroxysmal finger hematoma). Vasc Med 2019;24:361-6.

2 Yie K. Achenbach syndrome: a benign painful blue finger with tip sparing. Vasc Specialist Int 2019;35:251-5.

3 Takeuchi H, Uchida HA, Okuyama Y, et al. Acute idiopathic blue fingers: a young man with Achenbach's syndrome. BMJ Case Rep 2016;2016:bcr2016214491.

4 Kordzadeh A, Caine PL, Jonas A, et al. Is Achenbach's syndrome a surgical emergency? A systematic review. Eur I Trauma Emerg Surg 2016:42:439-43.

5 Jiménez PR, Ocampo Ml, Castañeda-Cardona C, et al. Achenbach's syndrome: Case report and systematic review of the literature. Rev Colomb Reumatol 2017;24:230-6.

6 Ada F, Kasimzade F. Analysis of 24 patients with Achenbach's syndrome. World I Clin Cases 2019;7:1103-10.

7 Notomi K, Harada T. Achenbach syndrome. CMAJ 2019:191:E584.

8 Suzuki J. Achenbach's syndrome in a 30-year-old healthy woman. Intern Med 2019;58:1807.

9 Yamamoto Y, Yamamoto S. Achenbach's syndrome. N Engl J Med 2017;376:e53. 
Copyright 2020 BMJ Publishing Group. All rights reserved. For permission to reuse any of this content visit https://www.bmj.com/company/products-services/rights-and-licensing/permissions/

BMJ Case Report Fellows may re-use this article for personal use and teaching without any further permission.

Become a Fellow of BMJ Case Reports today and you can:

- Submit as many cases as you like

Enjoy fast sympathetic peer review and rapid publication of accepted articles

Access all the published articles

Re-use any of the published material for personal use and teaching without further permission

Customer Service

If you have any further queries about your subscription, please contact our customer services team on +44 (0) 2071111105 or via email at support@bmj.com.

Visit casereports.bmj.com for more articles like this and to become a Fellow 